University of Windsor

Scholarship at UWindsor

1997

\title{
Influence of Feeding Habits on Organochlorine Contaminant Accumulation in Waterfowl on the Great Lakes
}

\author{
Edward John Mazak \\ University of Windsor \\ Hugh J. Maclsaac \\ University of Windsor \\ Mark Roy Servos \\ University of Windsor \\ Ray Hesslein \\ University of Windsor
}

Follow this and additional works at: https://scholar.uwindsor.ca/biologypub

Part of the Biology Commons

\section{Recommended Citation}

Mazak, Edward John; Maclsaac, Hugh J.; Servos, Mark Roy; and Hesslein, Ray, "Influence of Feeding Habits on Organochlorine Contaminant Accumulation in Waterfowl on the Great Lakes" (1997). Ecological Applications, 7, 4, 1133-1143.

https://scholar.uwindsor.ca/biologypub/1087

This Article is brought to you for free and open access by the Department of Biological Sciences at Scholarship at UWindsor. It has been accepted for inclusion in Biological Sciences Publications by an authorized administrator of Scholarship at UWindsor. For more information, please contact scholarship@uwindsor.ca. 


\title{
INFLUENCE OF FEEDING HABITS ON ORGANOCHLORINE CONTAMINANT ACCUMULATION IN WATERFOWL ON THE GREAT LAKES
}

\author{
Edward John Mazak, ${ }^{1}$ Hugh J. MacIsaac,,${ }^{1,2,5}$ Mark Roy Servos, ${ }^{3}$ And Ray Hesslein ${ }^{4}$ \\ ${ }^{1}$ Department of Biological Sciences, University of Windsor, Windsor, Ontario, Canada N9B 3P4 \\ ${ }^{2}$ Great Lakes Institute for Environmental Research, University of Windsor, Windsor, Ontario, Canada N9B 3P4 \\ ${ }^{3}$ Department of Environment, Canada Centre for Inland Waters, Burlington, Ontario, Canada L7R 4A6 \\ ${ }^{4}$ Department of Fisheries and Oceans, 501 University Cresent, Winnipeg, Manitoba, Canada R3T 2N6
}

Abstract. Zebra mussels (Dreissena polymorpha) are an important component of benthic communities in the Great Lakes and are exploited by a host of predators, including waterfowl. In this study, we analyze diet content and stable isotope and organochlorine contaminant patterns in Lesser Scaup (Aythya affinis), Greater Scaup (Aythya marila), Bufflehead (Bucephala albeola), Redhead (Aythya americana), Canvasback (Aythya valisineria), and Mallard (Anas platyrhynchos) collected from three sites (Fighting Island, western Lake Erie, Big Creek) in the lower Great Lakes. Lesser and Greater Scaup from Fighting Island were classified as either zebra mussel ( $\geq 67 \%$ of diet) or macrophyte ( $\geq 85 \%$ of diet) consumers. Bufflehead, Canvasback, Mallard, and Redhead consumed mainly $(\geq 89 \%)$ macrophyte at Fighting Island. Zebra mussel was the principal food of Lesser Scaup (>99\%), Greater Scaup (97\%), and Bufflehead (72\%) in western Lake Erie. Stable isotope analysis revealed enrichment of $\delta^{15} \mathrm{~N}$ in Lesser Scaup $(\geq 2.24 \%$ ), Greater Scaup $(\geq 1.28 \%$ ) , and Bufflehead $(\geq 0.63 \%$ ) that exploited mussels relative to conspecifics with macrophyte diets and relative to mussel prey.

Representative contaminants of low (hexachlorobenzene [HCB]), moderate (PCB [polychlorinated biphenyl] 153), and high (PCB 180) hydrophobicity were examined in waterfowl. Lipid-normalized concentrations of PCBs 153 and 180 were significantly higher in scaup and Bufflehead that consumed Dreissena than in individuals that ate mainly macrophytes. Among taxa that consumed primarily Dreissena, concentrations of PCBs 153 and 180 were significantly higher in individuals from Lake Erie than in those Fighting Island. Principal components analysis revealed broad differences in contaminant patterns of waterfowl based principally on diet.

Results from this study illustrate that Dreissena has become a primary food source of some waterfowl in the lower Great Lakes and serves as an effective conduit for transfer of persistent organic contaminants to higher trophic levels.

Key words: bioaccumulation; Dreissena; ducks; ecotoxicology; Great Lakes; Lake Erie; organochlorine contaminants; pesticides; polychlorinated biphenyls; principal components analysis; stable isotopes; waterfowl; zebra mussel.

\section{INTRODUCTION}

The Laurentian Great Lakes have been subject to species introductions since the onset of European settlement. More than 135 nonindigenous species have become established in the basin (see Mills et al. 1993). The zebra mussel, Dreissena polymorpha Pallas, established in the Great Lakes in 1985, and has since expanded its distribution to most major rivers and some inland lakes in temperate eastern North America. Zebra mussels are dominant contributors to benthic invertebrate abundance and biomass in many regions of the Great Lakes, including Saginaw Bay, Lake St. Clair, western Lake Erie, and the Detroit River (see Nalepa

Manuscript received 12 July 1996; revised 17 February 1997; accepted 24 March 1997; final version received 23 April 1997.

${ }^{5}$ Send reprint requests to this author. and Schloesser 1993). Well-established effects of Dreissena include enhanced water transparency, reduced phytoplankton concentration, and increases in densities of many benthic invertebrates (reviewed in MacIsaac 1996). Much less is known regarding the mussel's predator-prey relationships, and its effects on contaminant dynamics in invaded systems.

In the Great Lakes, Dreissena is consumed by a host of predators including crayfish and fishes (reviewed in MacIsaac 1996). Waterfowl are the predators most likely to have significant impacts on Dreissena populations owing to rapid numerical responses and strong feeding preferences of some species for bivalve prey. The number and duration of staging Greater Scaup (Aythya marila), Lesser Scaup (A. affinis), and Common Goldeneye (Bucephala clangula) increased dramatically subsequent to Dreissena establishment in the western basin of Lake Erie (Wormington and Leach 1992). Waterfowl 
predators quickly exploit recently established Dreissena populations. For example, Lesser Scaup preyed on Dreissena during the first winter following mussel establishment at a power plant on Lake Michigan (Mitchell and Carlson 1993). Predation by Greater Scaup, Lesser Scaup, Common Goldeneye, and Bufflehead (B. albeola) may strongly affect zebra mussel population biomass (Wormington and Leach 1992, Custer and Custer 1996). For example, ducks reduced Dreissena biomass by $57 \%$ at a nearshore habitat on western Lake Erie (Hamilton et al. 1994).

Dreissena has been used extensively as a sensitive biomonitor of organochlorine contaminants (e.g., Duursma et al. 1984, Bruner et al. 1994, Morrison et al. 1995, Roe and MacIsaac 1997). Brieger and Hunter (1993) reported significantly higher accumulations of PCB congeners in Dreissena than in native Lampsilis clams in the Great Lakes. Despite the mussel's significant bioaccumulation ability, information regarding biomagnification in Dreissena predators is lacking.

Like Dreissena, uptake of PCBs occurs very rapidly in waterfowl, and it may have important ecotoxicological implications. Gebauer and Weseloh (1993) reported that mallard (Anas platyrhynchos) accumulated PCBs to 5300 times initial values within $10 \mathrm{~d}$ of natural exposure. In a European study, caged Tufted Ducks (Aythya fuliga) fed Dreissena contaminated with an array of organic contaminants laid fewer eggs, abandoned nests more often, and had higher embryo and chick mortality rates than ducks fed less polluted mussels (de Kock and Bowmer 1993). Thus, consumption of contaminated Dreissena has the potential to adversely affect reproductive success of waterfowl in North America.

Seasonal and spatial variation in feeding habits of waterfowl may encumber assessments of dietary sources of contaminants because traditional diet analysis (i.e., gut content) reflects only the most recent feeding history. This problem can be resolved by using stable isotopes of $\mathrm{N}$ and $\mathrm{C}$ to characterize trophic relationships of complex food webs (Hobson 1990, Hamilton et al. 1992, Cabana and Rasmussen 1994, Kidd et al. 1995). The nitrogen isotopic ratio $\left(\delta^{15} \mathrm{~N}\right)$ is strongly indicative of the trophic position of an organism, whereas the carbon isotopic ratio $\left(\delta^{13} \mathrm{C}\right)$ can be useful in defining food sources (e.g., Kirilik et al. 1995, Riera and Richard 1996). The nitrogen and carbon isotopic ratios increase by $\sim 3.4$ and $1 \%$, respectively, per trophic level, owing to a combination of biological, chemical, and physical processes that cause differential assimilation of isotopes (Fry and Quinones 1994, Keough et al. 1996). Recent studies have also illustrated that $\delta^{15} \mathrm{~N}$ values are correlated with contaminant burden in a variety of freshwater taxa (Kirilik et al. 1995, Kidd et al. 1995).

The purpose of this study was to assess variation in contaminant burden in waterfowl in relation to diet, particularly with respect to individuals that exploit ze-

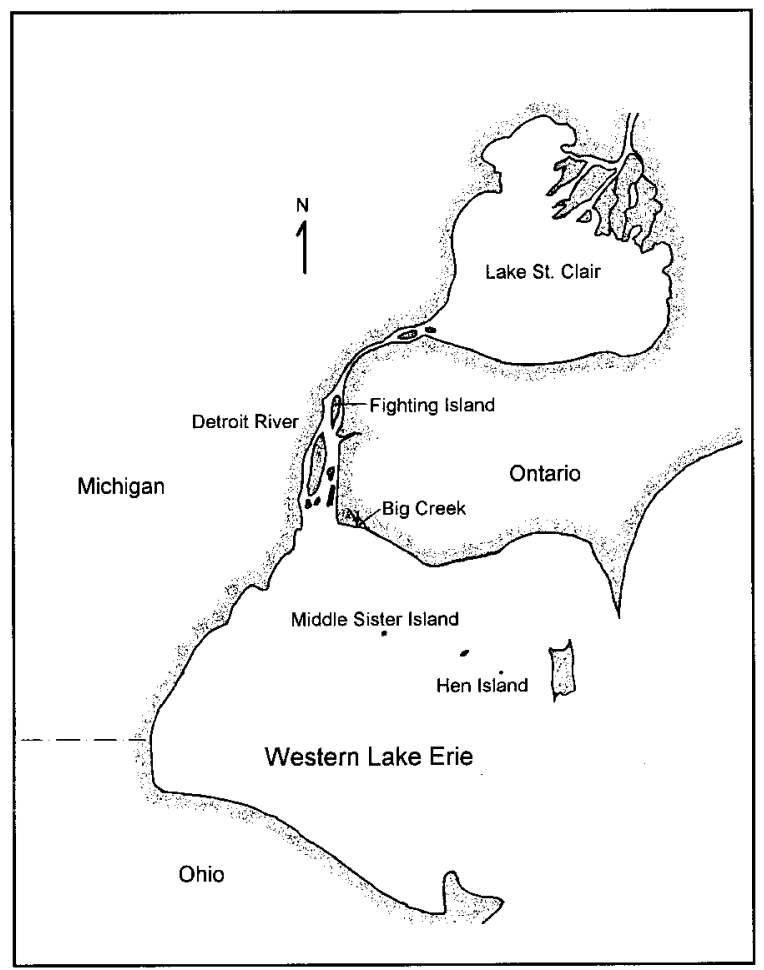

FIG. 1. Waterfowl collection sites in the lower Great Lakes. Ducks were collected in Lake Erie between Middle Sister Island, Hen Island, and the Canadian mainland, from the Detroit River near Fighting Island, and from Big Creek.

bra mussels. We complement conventional diet analysis with that of stable isotopes to determine the importance of zebra mussels as food and contaminant sources. We also assess relative contaminant exposure of waterfowl at three different locations in the lower Detroit Riverwestern Lake Erie ecosystem.

\section{Methods}

\section{Study sites and waterfowl collection}

Waterfowl were collected from three sites: Fighting Island in the lower Detroit River, Big Creek Marsh, and in western Lake Erie between Middle Sister and Hen Islands and the Canadian mainland (Fig. 1). Wetlands in the lower Detroit River are frequented by migrating and overwintering waterfowl (Prince et al. 1992). Shallow areas downstream of Fighting Island support extensive beds of macrophytes, i.e., Vallisneria americana, Elodea canadensis, and Potamogeton spp. (Davis and Erwin 1982). Gastropods and Dreissena occur on macrophytes and on mud flats in the Fighting Island area (Davis and Erwin 1982; E. Mazak, personal observation). Hen Island is located $8 \mathrm{~km}$ west of Pelee Island in western Lake Erie, while Middle Sister Island is located $15.7 \mathrm{~km}$ from the Canadian mainland in the central region of the basin. Mean depth in the basin is $7.3 \mathrm{~m}$, though deeper passages exist between islands and the mainland. Commercial fishermen deploy gill 
nets between the islands and the mainland throughout the ice-free season.

Seventy-one waterfowl were collected and analyzed for diet contents and organochlorine contaminants. Fighting Island and Big Creek waterfowl were donated by hunters. Lake ducks that had drowned in gill nets were furnished by commercial fishermen. Fighting Island taxa collected included Mallard, Canvasback ( $A y$ thya valisineria), Redhead (Aythya americana), Bufflehead, and Greater and Lesser Scaup. All ducks were collected between autumn 1993 and winter 1994. Hunted ducks were at identified feeding sites when killed, while drowned individuals were found at considerable depth (up to $7 \mathrm{~m}$ ) in areas supporting mussels and often had Dreissena in their mouth and esophagus.

Duck mass was determined to the nearest $25 \mathrm{~g}$ using a spring balance (Ohaus/Canadawide Scientific, Ottawa, Ontario, Canada) length was measured $( \pm 0.25 \mathrm{~cm})$, the digestive tract was removed, and liver and/or wing tissues were excised and wrapped in hexane-rinsed aluminum foil and frozen pending organochlorine contaminant and stable isotope analyses. Species, age, and sex of waterfowl were determined according to Carney (1992).

The esophagus, proventriculus, and gizzard of each duck were analyzed for diet contents. Decomposition of food items, particularly in the gizzard, limited taxonomic resolution of diet contents. Diet items were categorized into four main fractions: Dreissena, macrophyte (mainly Elodea, Vallisneria, and Potamogeton spp.), snail, or amphipod (Gammarus fasciatus). Right valve and septa lengths of whole mussels obtained from duck digestive tracts were measured to the nearest 0.01 mm using an ocular micrometer and dissecting microscope (Hamilton 1992). Right valve length (VL) was estimated from right septa length (SL) for mussel shell fragments recovered from waterfowl gizzards as $\mathrm{VL}=$ $0.29+8.32 \mathrm{SL}\left(r^{2}=0.92\right)$. Biomass of diet contents was determined to the nearest $0.5 \mathrm{mg}$ with an electronic balance (A\&D, Model FX-200, Milpitas, California, USA) after samples were air dried at $20^{\circ} \mathrm{C}$ for at least $72 \mathrm{~h}$.

Samples of waterfowl diet items were collected from field sites for contaminant and stable isotope analysis. Macrophytes from Fighting Island were collected in $1.5 \mathrm{~m}$ of water during August 1994, while snails and Dreissena were obtained by benthic dredge (mesh size $2 \mathrm{~mm}$ ) from 1.5 to $2.5 \mathrm{~m}$ depth during December 1994 . Dreissena, macrophytes, and gastropod samples from Middle Sister Island were collected during September 1994 in $2-3 \mathrm{~m}$ of water.

\section{Contaminant and isotope analysis}

Contaminant concentrations were measured directly in livers of 62 ducks, of which 11 individuals were also assayed for concentrations in wing tissues. Lipid-normalized liver concentrations were regressed on lipidnormalized wing concentrations for these 11 individ- uals. Lipid-adjusted liver concentrations were calculated for nine additional ducks for which only lipidadjusted wing values were available. Lipid-adjusted wing and liver values were highly correlated, with the coefficient of determination $\left(r^{2}\right)$ ranging between 0.72 for pentachlorobenzene (QCB) and PCB 28 and 0.99 for PCBs 153 and 194. The number of individuals analyzed for contaminants ranged between 3 and 10 for each group of species classified by site and diet (see Table 1).

Sample preparation and gas chromatography procedures for organochlorine contaminant analyses of waterfowl wing and/or liver tissue, Dreissena soft tissues, and macrophyte aboveground tissues follow Lazar et al. (1992). A small portion of each animal sample was used for gravimetric determination of lipid content (see Lazar et al. 1992). Contaminant analyses were conducted on a Hewlett Packard-5890 Series II Gas Chromatography $/{ }^{63} \mathrm{~N}$-Electron Capture Detector instrument (Hewlett-Packard, Mississauga, Ontario, Canada). Canadian Wildlife Service Standards (CWS-RSM 8229-Herring Gull egg pool) were run as references every 6-8 samples. Sixty-five contaminants encompassing a broad array of pesticides, chlorinated hydrocarbons, and PCBs were assayed in waterfowl and prey items. Twenty-six chemicals were deleted from analysis because of coelution problems or because the majority of samples contained nondetectable $(<0.05$ $\mu \mathrm{g} / \mathrm{kg}$ wet mass) levels of contaminant. If more than half of the samples had detectable levels of a particular contaminant, nondetectable values were replaced by random numbers between 0.00 and $0.05 \mu \mathrm{g} / \mathrm{kg}$ wet mass generated using Quattro Pro. All animal wet mass chemical concentrations were lipid normalized; mean lipid content in liver and wing tissue varied between 3.3 and $6.5 \%$, and was typically slightly higher in ducks from Lake Erie than from either of the other sites (see Table 1). Wet mass contaminant levels in macrophytes were normalized based on organic carbon content. PCB identification numbers and associated octanol-water partition coefficients $\left(K_{\mathrm{ow}}\right.$; a measure of hydrophobicity) are based on the IUPAC classification system (Shiu and Mackay 1986; Table 1).

Stable carbon and nitrogen isotope analyses were conducted on wing tissue from 33 waterfowl and 9 macrophyte, snail, and Dreissena diet samples collected from the field. Waterfowl tissues were trimmed to remove visible lipid, and cut into 5-mm square cubes. Dreissena and snails collected from Lake Erie were shucked, and the soft tissues diced. Samples (1 g) were placed in a glass-stoppered flask and swirled in $100 \mathrm{~mL}$ of acetone suspension for $15 \mathrm{~min}$. Samples were rinsed with $50 \mathrm{~mL}$ dichloromethane for $1 \mathrm{~min}$, dried for $48-72 \mathrm{~h}$ at $60^{\circ} \mathrm{C}$, and powdered with mortar and pestle. Plant material from Fighting Island was dried at $60^{\circ} \mathrm{C}$, then powdered in a Wiley mill. Samples were analyzed in an automated elemental analyzer (Carlo Erba NA 1500) attached to a VG Optima au- 
TABLE 1. Concentration (mean $\pm 1 \mathrm{SE}$ ) of representative low- $K_{\mathrm{OW}}$ (hexachlorophenol [HCB], PCB 28), mid- $K_{\mathrm{OW}}$ (PCBs 149 , 153 ), and high- $K_{\mathrm{OW}}$ (PCBs 180, 194) organochlorine contaminants, and total PCB concentration, in waterfowl and primary prey. Mass and length are mean values.

\begin{tabular}{|c|c|c|c|c|c|c|c|c|c|c|}
\hline \multirow[b]{2}{*}{ Species } & \multirow[b]{2}{*}{ Site } & \multirow{2}{*}{$\begin{array}{l}\text { Sam- } \\
\text { ple } \\
\text { size }\end{array}$} & \multirow[b]{2}{*}{$\begin{array}{l}\text { Male } \\
(\%)\end{array}$} & \multirow[b]{2}{*}{$\begin{array}{c}\text { Adult } \\
(\%)\end{array}$} & \multirow[b]{2}{*}{$\begin{array}{l}\text { Mass } \\
(\mathrm{g})\end{array}$} & \multirow[b]{2}{*}{$\begin{array}{l}\text { Length } \\
(\mathrm{cm})\end{array}$} & \multirow[b]{2}{*}{ Diet } & \multicolumn{3}{|c|}{$\begin{array}{l}\text { Concentration } \\
(\mu \mathrm{g} / \mathrm{kg} \text { lipid })\end{array}$} \\
\hline & & & & & & & & $\begin{array}{c}\text { HCB } \\
(5.50) \dagger\end{array}$ & $\begin{array}{c}\text { PCB 28 } \\
(5.67) \\
\end{array}$ & $\begin{array}{c}\text { PCB } 149 \\
(6.67)\end{array}$ \\
\hline Mallard & $\mathrm{BC}$ & 4 & 50 & 75 & 1238 & 59 & & $4 \pm 1$ & $4 \pm 1$ & $14 \pm 9$ \\
\hline Mallard & FI & 3 & 67 & 100 & 1067 & 53 & $\mathrm{~m}$ & $4 \pm 1$ & $2 \pm 0$ & $13 \pm 5$ \\
\hline Canvasback & FI & 6 & 50 & 67 & 1193 & 54 & $\mathrm{~m}$ & $23 \pm 15$ & $3 \pm 0$ & $17 \pm 10$ \\
\hline Redhead & FI & 3 & 33 & 67 & 1085 & 50 & $\mathrm{~mm}$ & $5 \pm 2$ & $3 \pm 1$ & $9 \pm 4$ \\
\hline Bufflehead & FI & 4 & 75 & 0 & 498 & 35 & $\mathrm{~m}$ & $37 \pm 5$ & $9 \pm 3$ & $32 \pm 6$ \\
\hline Bufflehead & LE & 5 & 80 & 20 & 479 & 37 & $\mathrm{zm}$ & $30 \pm 5$ & $8 \pm 2$ & $154 \pm 10$ \\
\hline Lesser Scaup & FI & 4 & 50 & 0 & 861 & 44 & $\mathrm{~m}$ & $14 \pm 1$ & $2 \pm 0$ & $12 \pm 5$ \\
\hline Lesser Scaup & FI & 3 & 100 & 33 & 883 & 42 & $\mathrm{zm}$ & $30 \pm 3$ & $2 \pm 1$ & $9 \pm 4$ \\
\hline Lesser Scaup & LE & 8 & 63 & 75 & 985 & 44 & $\mathrm{zm}$ & $23 \pm 2$ & $4 \pm 1$ & $114 \pm 20$ \\
\hline Greater Scaup & FI & 4 & 50 & 50 & 1028 & 43 & $\mathrm{~m}$ & $63 \pm 46$ & $2 \pm 0$ & $14 \pm 2$ \\
\hline Greater Scaup & FI & 3 & 33 & 33 & 1000 & 40 & $\mathrm{zm}$ & $36 \pm 23$ & $1 \pm 0$ & $7 \pm 5$ \\
\hline Greater Scaup & LE & 5 & 40 & 40 & 1270 & 48 & $\mathrm{zm}$ & $42 \pm 10$ & $6 \pm 1$ & $147 \pm 13$ \\
\hline Macrophyte $\$$ & FI & 6 & & & & & & $<1 \pm 0$ & $\mathrm{ND}$ & $<1 \pm 0$ \\
\hline Zebra mussel & FI & 2 & & & & & & $78 \pm 16$ & $4 \pm 0$ & $190 \pm 37$ \\
\hline Zebra mussel & LE & 5 & & & & & & $4 \pm 1$ & $4 \pm 1$ & $193 \pm 7$ \\
\hline
\end{tabular}

Note: Site key: $\mathrm{BC}=$ Big Creek, FI $=$ Fighting Island, LE $=$ Lake Erie. Diet refers to major prey type found in the digestive tract. Diet key: $\mathrm{m}=$ macrophyte, $\mathrm{zm}=$ Dreissena $. \mathrm{ND}=$ not detectable.

$\dagger$ Values in parentheses are $\log K_{\text {Ow }}$.

\$ Macrophyte (Elodea canadensis, Myriophyllum spicatum) data from R. Russell (unpublished data) and are adjusted for organic carbon content. All other contaminant data are lipid adjusted.

tomated mass spectrometer (Phisons Instruments, Athenway, Middlewich, Chesire, UK), which was equipped with a cryogenic trapping system for $\mathrm{CO}_{2}$ and $\mathrm{N}_{2}$. Samples were oxidized in an oxygen atmosphere at $1100^{\circ} \mathrm{C}$, then reduced over copper at $650^{\circ} \mathrm{C}$. Water was removed by magnesium perchlorate and the sample gases trapped from the helium stream. After helium was pumped away, samples were released to the mass spectrometer through the changeover valve of a dual inlet system by which the sample gas isotope ratio could be compared to the reference gas of the system. Standardization is relative to PDB (Pee Dee Belemnite) for carbon and air for nitrogen. The ratio of the heavier to the lighter isotope in the sample relative to the standard $(\% o)$ is calculated as

$$
\delta X=\left(\frac{R_{\text {sample }}}{R_{\text {standard }}}-1\right) \times 1000
$$

where $X$ is ${ }^{13} \mathrm{C}$ or ${ }^{15} \mathrm{~N}$ and $R$ is the corresponding ratio ${ }^{13} \mathrm{C}:{ }^{12} \mathrm{C}$ or ${ }^{15} \mathrm{~N}:{ }^{14} \mathrm{~N}$. The standard deviation of replicate analyses is typically 0.1 and $0.3 \%$ for ${ }^{13} \mathrm{C}$ and ${ }^{15} \mathrm{~N}$, respectively (Hesslein et al. 1989).

\section{Statistical analysis}

Examination of Fighting Island Greater and Lesser Scaup revealed that individuals consumed either mussels or macrophytes as the primary diet component. These individuals were thus classified as mussel consumers or macrophyte consumers. In order to justify this classification scheme, a two-way ANOVA was conducted on the proportion of Dreissena in diets of all Lesser and Greater Scaup from Fighting Island, with duck species and diet as main effects. Similarly, a two- way ANOVA with species and collection site as main effects was conducted on the proportion of Dreissena in diet of Greater and Lesser Scaup mussel consumers from Fighting Island and Lake Erie. Differences in the proportion of Dreissena in diets of Lake Erie and Fighting Island bufflehead were explored using Student's $t$ test.

Differences in utilization of macrophytes by Fighting Island waterfowl (Canvasback, Redhead, Mallard, and Greater and Lesser scaup) that consumed mainly macrophytes were explored using one-way ANOVA. All proportion diet data were arcsine square-root transformed prior to analyses. All transformed data were homoscedastic (Cochran's test, $\alpha=0.01$ ).

Size distributions of mussels consumed by Bufflehead, Lesser Scaup, and Greater Scaup from Lake Erie were compared using Kolmogorov-Smirnov tests at an adjusted significance level $(\alpha)$ of 0.02 .

All statistical analyses of variation in contaminant concentrations utilized $\log (x+1)$-transformed, lipidnormalized data, and were limited to three compounds (HCB, PCB 153, and PCB 180). These chemicals were selected as representatives of low-, mid- and high- $K_{\text {ow }}$ compounds and because none of the compounds are metabolized. Variation in contaminant concentrations of these compounds in Lesser and Greater Scaup from Fighting Island that consumed plant or mussel diets was assessed using two-way multivariate analysis of variance (MANOVA) with species and diet main effects. Species and site effects were analyzed for these compounds using two-way MANOVA on Greater and Lesser Scaup from Fighting Island and Lake Erie that consumed mussel diets. Species differences in concen- 
TABLE 1. Continued.

\begin{tabular}{cccc}
\hline \hline \multicolumn{4}{c}{$\begin{array}{c}\text { Concentration } \\
(\mu \mathrm{g} / \mathrm{kg} \text { lipid })\end{array}$} \\
\hline PCB 153 & PCB 180 & PCB 194 & Total \\
$(6.92)$ & $(7.36)$ & $(7.80)$ & PCB \\
\hline $30 \pm 6$ & $14 \pm 5$ & $3 \pm 0$ & $347 \pm 149$ \\
$29 \pm 14$ & $19 \pm 8$ & $3 \pm 2$ & $330 \pm 172$ \\
$67 \pm 42$ & $43 \pm 8$ & $10 \pm 7$ & $433 \pm 238$ \\
$16 \pm 5$ & $7 \pm 2$ & $1 \pm 0$ & $179 \pm 75$ \\
$73 \pm 19$ & $55 \pm 12$ & $9 \pm 2$ & $693 \pm 154$ \\
$462 \pm 93$ & $446 \pm 93$ & $75 \pm 15$ & $3722 \pm 496$ \\
$29 \pm 20$ & $17 \pm 15$ & $4 \pm 4$ & $300 \pm 190$ \\
$131 \pm 55$ & $113 \pm 35$ & $16 \pm 7$ & $914 \pm 317$ \\
$298 \pm 77$ & $340 \pm 64$ & $63 \pm 11$ & $2734 \pm 483$ \\
$16 \pm 3$ & $18 \pm 5$ & $2 \pm 0$ & $185 \pm 21$ \\
$200 \pm 182$ & $187 \pm 173$ & $33 \pm 29$ & $1462 \pm 1191$ \\
$457 \pm 165$ & $477 \pm 135$ & $79 \pm 25$ & $4464 \pm 1363$ \\
$<1 \pm 0$ & $<1 \pm 0$ & $<1 \pm 0$ & $25 \pm 2$ \\
$203 \pm 35$ & $99 \pm 3$ & $20 \pm 3$ & $3375 \pm 580$ \\
$224 \pm 13$ & $169 \pm 10$ & $29 \pm 2$ & $2359 \pm 97$ \\
\hline
\end{tabular}

trations of these compounds were explored for waterfowl from Fighting Island that consumed macrophyte diets using one-way MANOVA.

Site-based variation in contaminant concentrations was also analyzed for Bufflehead from Lake Erie and Fighting Island, and, separately, for Mallard from Big Creek and Fighting Island, using Bonferroni-adjusted ( $\alpha=0.015)$ Student's $t$ tests.

Principal components analysis (PCA) was performed on $\log (x+1)$-transformed, lipid-adjusted chemical concentrations using nine compounds. In addition to the chemicals listed above, two other representative low- (QCB, PCB 28), mid- (PCBs 149, 118), and high(PCBs 174,194$) K_{\text {ow }}$ compounds were utilized in the model. The model employed a correlation matrix and varimax rotation (SYSTAT 1992). Two-way MANOVA was conducted on the first three principal component factor scores for scaup from Fighting Island to assess species and diet main effects. Similarly, factor scores for the first three principal components for scaup from Fighting Island and Lake Erie were analyzed using twoway MANOVA to assess species and location main effects. Variation in species factor scores for all waterfowl from Fighting Island that consumed mainly macrophytes was examined using one-way MANOVA. Variation in PCA factor scores of Bufflehead and Mallard from different sites was analyzed separately using $t$ tests with Bonferroni adjustments $(\alpha=0.015)$.

Carbon and nitrogen isotope patterns in Greater and Lesser Scaup from Fighting Island were subject to a two-way MANOVA to assess effects of species and diet. MANOVA was also used to test for species and site differences in $\mathrm{N}$ and $\mathrm{C}$ isotope ratios for Fighting Island and Lake Erie scaup that consumed mainly Dreissena. One-way ANOVAs followed by Dunnett's one-sided means tests were run separately for ${ }^{13} \mathrm{C}$ and ${ }^{15} \mathrm{~N}$ stable isotopes to determine whether isotope en-
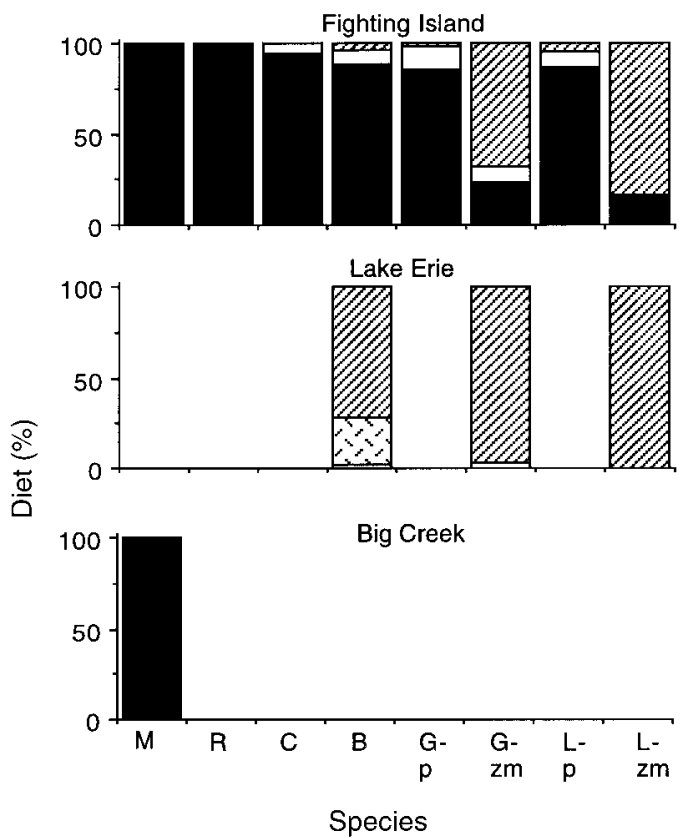

FIG. 2. Mean diet composition of waterfowl from Fighting Island, western Lake Erie, and Big Creek, Ontario. Diet key: solid bars = macrophytes; open bars = snails; hatched (diagonally striped) bars = zebra mussels; stippled bars = amphipods. Species key: $\mathrm{M}=$ Mallard; $\mathrm{R}=$ Redhead; $\mathrm{C}=$ Canvasback; B = Bufflehead; G-p = Greater Scaup, plant consumer; G-zm = Greater Scaup, mussel consumer; $\mathrm{L}-\mathrm{p}=$ Lesser Scaup, plant consumer; L-zm = Lesser Scaup, mussel consumer.

richment occurred in waterfowl predators relative to principal food (SYSTAT 1992). Tests were conducted on Lake Erie waterfowl that consumed Dreissena as a principal diet item, and, separately, on all Fighting Island waterfowl that consumed macrophytes.

\section{RESUlts}

Physical examination revealed no gross external or internal abnormalities in any waterfowl in the study. Mallard from Big Creek and Greater Scaup from Lake Erie were the largest and heaviest waterfowl, respectively, while Bufflehead were the smallest and lightest ducks (Table 1). Lesser and Greater Scaup from Lake Erie were slightly larger and heavier than conspecifics from Fighting Island (Table 1).

Lesser and Greater Scaup from Lake Erie consumed Dreissena almost exclusively (>97\%; Fig. 2). By contrast, individuals from Fighting Island could be classified into those that ate either mainly Dreissena or mainly macrophytes. Scaup classified as mussel consumers ate significantly more Dreissena than those classified as macrophyte consumers $(F=225$, df $=1$, $17, P<0.001)$; species $(F=3.8$, df $=1,17, P=$ $0.069)$ and species $\times \operatorname{diet}(F=1.4, \mathrm{df}=1,17, P=$ 0.241 ) differences were not evident.

Diets of scaup from Lake Erie also contained more Dreissena than those classified as mussel consumers 


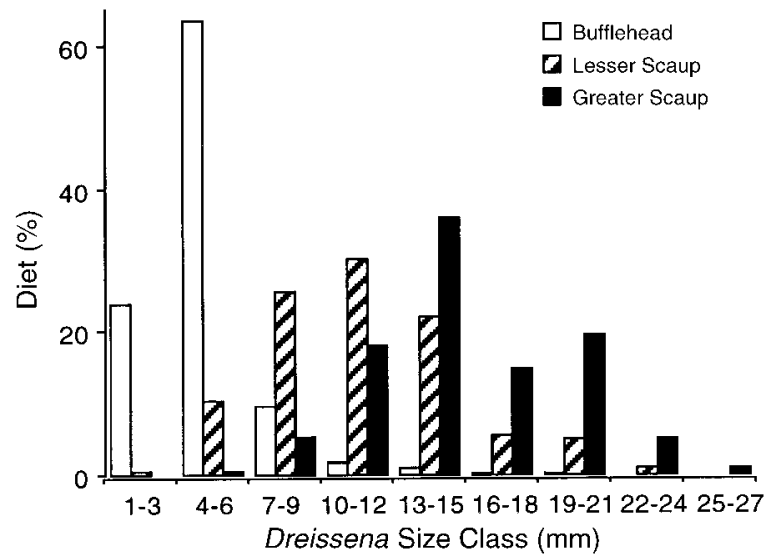

FIG. 3. Size composition of Dreissena consumed by Bufflehead, Lesser Scaup, and Greater Scaup from Lake Erie.

from Fighting Island ( $F=133$, df $=1,19, P<0.001)$. Dreissena in diet was also slightly but significantly higher for Lesser Scaup than for Greater Scaup at the two locations ( $F=18$, df $=1,19, P<0.001$; Fig. 2).

Diet of Bufflehead from Lake Erie contained a higher proportion Dreissena than individuals from Fighting Island, diets of which were dominated by macrophytes $(t=9$, df $=10, P<0.001$; Fig. 2). Bufflehead from Lake Erie consumed no macrophytes, though amphipods were a common diet component. Bufflehead from Lake Erie also consumed a smaller proportion Dreissena than either scaup species. Mussels consumed by Bufflehead were also significantly smaller than those eaten by Lesser Scaup, which, in turn, ate smaller mussels than greater scaup (Kolmogorov-Smirnov tests; Fig. 3).

Diets of Canvasback, Redhead, and all Mallard were heavily dominated (>94\%) by macrophytes (Fig. 2). Use of macrophytes as a food source did not differ in any Fighting Island waterfowl, diets of which consisted mainly of non-Dreissena items $(F=1.3$, df $=5,33$, $P=0.271)$.

Concentrations of most contaminants in waterfowl were strongly related to diet and location but not to gender or age (Table 1). For example, no contaminant averaged $>70 \mu \mathrm{g} / \mathrm{kg}$ lipid in any Fighting Island waterfowl that consumed primarily macrophytes except for octachlorostyrene (OCS) and PCBs 138 and 153 in Bufflehead. By contrast, Greater Scaup from Fighting Island that consumed mainly Dreissena exceeded 70 $\mu \mathrm{g} / \mathrm{kg}$ lipid for a wide range of contaminants, including OCS and PCBs 118, 138, 153, and 180. Lesser Scaup from Fighting Island that consumed mainly Dreissena exceeded $70 \mu \mathrm{g} / \mathrm{kg}$ lipid for PCBs 153, 138, and 180 . Concentrations of most mid- and high- $K_{\text {ow }}$ compounds were much higher in Lake Erie waterfowl. For example, Lake Erie Bufflehead, Greater Scaup, and Lesser Scaup exceeded $150 \mu \mathrm{g} / \mathrm{kg}$ lipid for an array of compounds, including OCS and PCBs 138, 153, and 180. Coplanar
PCBs 77, 126, 169, and 189 were present in low concentrations $(<10 \mu \mathrm{g} / \mathrm{kg}$ lipid $)$ in all waterfowl.

Fighting Island waterfowl that consumed mainly mussels had consistently higher concentrations of high$K_{\text {ow }}$ contaminants than co-occurring conspecifics that had little or no Dreissena in the diet (see Table 1). Among Fighting Island scaup, for example, concentrations of contaminants representative of the different compound hydrophobicity $\left(K_{\mathrm{ow}}\right)$ classes varied by diet $(F=3.9, \mathrm{df}=3,15, P=0.030$, MANOVA $)$, though differences were limited to mid- $K_{\text {ow }}$ (PCB 153; $F=$ 8.9 , df $=1,17, P=0.008)$ and high- $K_{\text {ow }}(\mathrm{PCB} 180$; $F=12.8$, df $=1,17, P=0.002$ ) congeners. No species or species $\times$ diet interactions were detected among Fighting Island scaup $(P=0.606$ and 0.524 , respectively; MANOVA).

Average total PCB concentration in Lake Erie lesser and greater scaup were 3.5 and 2.7 times higher, respectively, than in conspecifics from Fighting Island that consumed mainly Dreissena (Table 1). While contaminant concentrations were significantly higher in waterfowl from Lake Erie $(F=6.9 ; \mathrm{df}=3,17 ; P=$ 0.003 , MANOVA), these differences were also limited to mid- and high- $K_{\text {ow }}$ compounds $(P \leq 0.004$, ANOVAs). No species or species $\times$ site interaction differences in concentrations of representative chemicals were detected among scaup from Lake Erie and Fighting Island (MANOVA, $P>0.500$ ).

Site differences in chemical concentrations were also apparent in Bufflehead. Concentrations of most midand high- $K_{\mathrm{ow}}$ contaminants were between 2 and 10 times higher in individuals from Lake Erie relative to those from Fighting Island. For example, bufflehead from Lake Erie had significantly higher concentrations of PCB $153(t=5.8$, df $=10, P=0.002)$ and PCB $180(t=5.0, \mathrm{df}=10, P=0.0005)$, though these site differences were confounded by diet (Fig. 2; Table 1). Variation in low- $K_{\text {ow }}$ congeners was similar among sites (e.g., HCB; $t=1.2$, df $=10, P=0.28$ ).

Mallard from Fighting Island and Big Creek did not vary with respect to concentrations of any of the compounds tested ( $t$ tests, $P>0.50$ ).

Principal components (PC) analysis was conducted on contaminant data in waterfowl using nine compounds of varying $K_{\mathrm{ow}}$. PC1 accounted for $41 \%$ of original data variability, and was determined primarily by mid- and high- $K_{\text {ow }}$ congeners (PCBs $180,153,194$, and 118). PC2 and PC3 accounted for an additional $13 \%$ and $12 \%$ of data variability and were, respectively, determined by the low- $K_{\text {ow }}$ compounds QCB and PCB 28.

Waterfowl separated clearly on PC1 based on diet (Fig. 4). In general, waterfowl that consumed mussels had much higher PC1 scores than those than ate macrophyte diets (Fig. 4). For example, scores of Lesser and Greater Scaup from Fighting Island varied by diet $(F=4.9, \mathrm{df}=3,15, P=0.014$, MANOVA $)$, though differences were limited to PC axis 1 only $(F=15$, df $=1,17, P=0.0012$, ANOVA). Waterfowl with mussel 


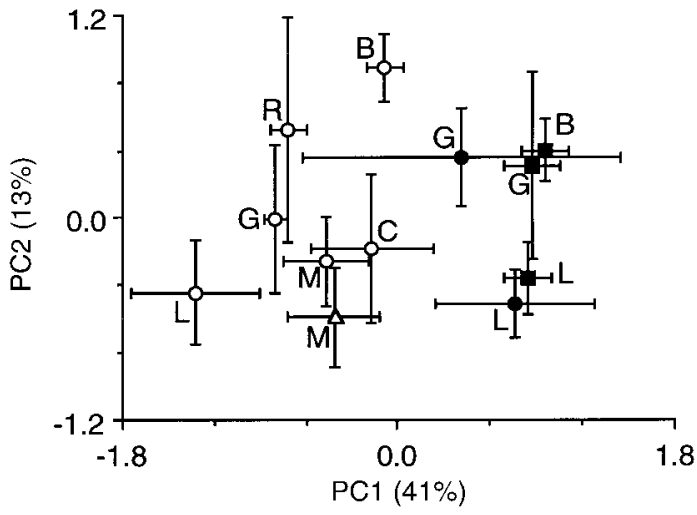

FIG. 4. Mean ( \pm 1 SE) principal components scores of Mallard (M), Redhead (R), Canvasback (C), Greater Scaup (G), Lesser Scaup (L), and Bufflehead (B). PCA 1 scores for scaup from Lake Erie $(\square)$ were similar to those from Fighting Island (-) that ate mainly Dreissena, but not those from Fighting Island that ate mainly macrophytes $(\bigcirc)$. Mallard from Fighting Island $(\bigcirc)$ and $\operatorname{Big}$ Creek $(\triangle)$ ate only macrophytes and had similar PCA scores.

diet from this site had much higher concentrations of PCBs 180, 153, 194, and 118 than individuals with a plant diet. No species or species $\times$ diet interactions were evident $(P>0.4$, MANOVA).

PC scores of scaup from Fighting Island and Lake Erie that consumed mussel diets did not vary by species $(P=0.34$, MANOVA $)$, by site $(P=0.45$, MANOVA $)$, or by an interaction of these main effects $(P=0.75$, MANOVA), though there was considerable variation in species' PC2 scores (Fig. 4).

Lake Erie bufflehead had higher PC1 scores than individuals from Fighting Island $(t=5.4$, df $=10, P$ $=0.0003)$, though differences between PC2 and PC3 scores were insignificant $(t$ tests, $P>0.05)$. Mallard from Fighting Island and Big Creek had very similar principal components scores ( $t$ tests, $P>0.05$ ). Likewise, all waterfowl from Fighting Island that consumed mainly macrophyte diets did not differ with respect to scores on the first three PC axes $(P>0.10$, MANOVA).

Stable isotope ratios of $\mathrm{N}$ and $\mathrm{C}$ in Fighting Island scaup did not vary by species $(F=0.4$, df $=2,7, P$ $>0.10$, MANOVA $)$ or by diet $(F=4.2, \mathrm{df}=2,7, P$ $=0.06)$, though the latter result likely reflects small sample sizes (Fig. 5; Tabachnick and Fidell 1996). As evidence, univariate analysis of the latter result was significant for nitrogen $(F=8.9$, df $=1,8, P<0.02)$, indicating trophic enrichment in mussel predators. Moreover, ratios of $\delta^{15} \mathrm{~N}$ and $\delta^{13} \mathrm{C}$ isotopes in scaup that consumed mussels did not vary by species $(F=0.52$, $\mathrm{df}=2,7, P>0.10)$ or by location $(F=0.36, \mathrm{df}=$ $2,7, P>0.10$, MANOVA).

All Lake Erie waterfowl that consumed mussels had isotope ratios that were very similar with respect to both $\delta^{15} \mathrm{~N}$ and $\delta^{13} \mathrm{C}$ (Fig. 5). $\delta^{15} \mathrm{~N}$ ratios were enriched by $\geq 2.3 \%$ o in mussel predators relative to Dreissena,

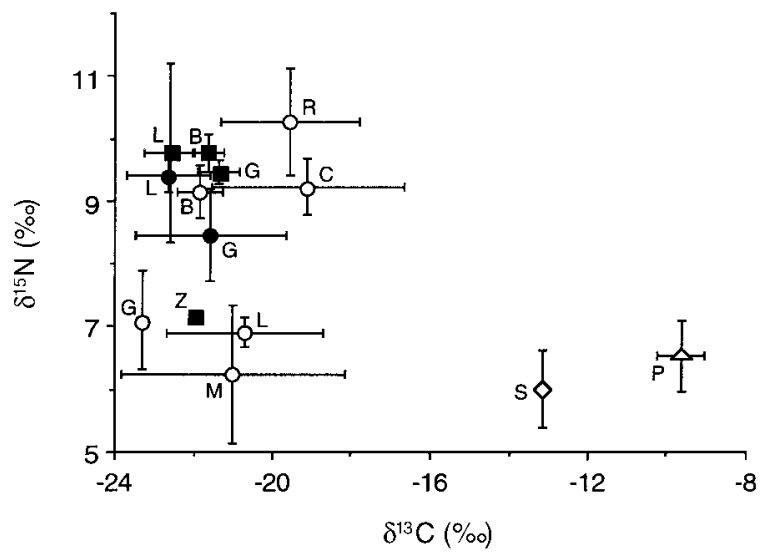

FIG. 5. Mean ( $\pm 1 \mathrm{SE})$ stable isotope patterns of waterfowl and prey from Lake Erie (squares) and Fighting Island (circles). Mussel predators (solid symbols) exhibit trophic $(\delta \mathrm{N})$ enrichment relative to conspecifics that ate macrophyte diets (open symbols). Waterfowl species codes are as in Fig. 4. Prey species symbols: $\mathrm{Z}=$ Dreissena, $\mathrm{S}=$ snail, $\mathrm{P}=$ Vallisneria americana, Potamogeton spp., and Elodea canadensis. Standard errors less than symbol thickness are not shown.

though differences among groups were not significant $(F=1.17$, df $=3,8, P=0.37$, ANOVA $)$.

All Fighting Island ducks that consumed macrophytes were significantly depleted with respect to $\delta^{13} \mathrm{C}$ relative to macrophytes (Dunnett's test, $P<0.01$; Fig. 5). In addition, Redhead, Canvasback, and Bufflehead were enriched in $\delta^{15} \mathrm{~N}$ by $2-4 \%$ relative to macrophytes (Dunnett's test, $P<0.01$ ), while values for Mallard and Lesser and Greater Scaup were similar to those of macrophytes (Fig. 5).

\section{Discussion}

Detroit River sediments are highly polluted with organochlorine compounds. River inputs serve as the primary source $(73 \%)$ of organic contaminants to western Lake Erie (Carter and Hites 1992). Koslowski et al. (1994) documented significant accumulations of a wide array of organochlorine compounds in the western Lake Erie food web, and argued that trophic interactions play an important role in contaminant exposure. Results from this study establish that recent diet is a good predictor of contaminant exposure in lower Great Lakes waterfowl, and that these patterns are generally corroborated by stable isotope analyses. Ducks that consumed Dreissena typically displayed elevated contaminant concentrations and were enriched with respect to $\delta{ }^{15} \mathrm{~N}$ relative to co-occurring individuals that ate little or no Dreissena (Fig. 5; Table 1).

Uptake of PCBs occurs very rapidly in waterfowl (Gebauer and Weseloh 1993). Mallard exposed to dieldrin achieve steady-state concentrations in muscle, liver, and fat within $8 \mathrm{~d}$ (Nebeker et al. 1994). The rapidity of uptake indicates that migrating waterfowl are susceptible to short-term contaminant exposure, and body burdens reflect recent exposure to contami- 
nants. High contaminant levels in ducks with mussel diet almost certainly reflect local exposure. Every duck examined for organic contaminants that had a diet of zebra mussels was collected between late November and mid-December or during mid-April, at least $3 \mathrm{wk}$ after the ducks had arrived on western Lake Erie in mass migrations (G. Ives, personal communication). This time differential should have been sufficient to permit significant accumulation of organochlorine contaminants. Conversely, it is unlikely that the ducks became contaminated via exploitation of another food source prior to migrating to Lake Erie. The ducks arrive on Lake Erie after migrating south from Alaskan breeding grounds through Saskatchewan, Manitoba, and the upper Great Lakes (Barclay and Zingo 1993). Hatching-year scaup from Saskatchewan contain extremely low levels of organochlororine compounds, indicating that they become contaminated after migrating through the prairies (E. Mazak, unpublished data). The lower Detroit River-western Lake Erie corridor is the most contaminated region visited by Greater Scaup on the flyway that takes them from Alaska through the Lake Erie region (Carter and Hites 1992, Barclay and Zingo 1993, Robertson et al. 1993). Considering that zebra mussels bioaccumulate organic contaminants more than native Great Lakes' bivalves (Brieger and Hunter 1993), and that they constitute between 90 and $99 \%$ of benthic invertebrate biomass (Dahl et al. 1995), it is unlikely that scaup encounter a food supply as contaminated and as abundant as that of Dreissena in western Lake Erie. Local exposure to contaminants also is suggested by chemical profiles for all three species of Lake Erie waterfowl. While concentrations of compounds differed among species, the proportional abundance of 33 congeners to total PCB concentration was consistent among species and similar to zebra mussels from Lake Erie (Mazak 1995).

Concentrations of contaminants in liver and wing were highly correlated for all but 6 of the 39 compounds studied. Mean total lipid-adjusted PCB levels were an average of 1.23 times higher in liver than in wing muscle. The correlation between concentrations of contaminants in liver and muscle was lowest for low$K_{\text {ow }}$ compounds (e.g., QCB, PCB 28), reflecting the rapid depuration kinetics of these contaminants from liver (Morrison et al. 1995).

Many studies have demonstrated that availability of Dreissena prey can influence waterfowl abundance and distribution (Stańczykowska et al. 1990, Wormington and Leach 1992, Cleven and Frenzel 1993, Mitchell and Carlson 1993). In turn, migrant or resident waterfowl may have significant impacts on mussel population biomass and size structure (Stańczykowska et al. 1990, Cleven and Frenzel 1993). The size of mussels consumed may affect waterfowl exposure to contaminants because contaminant concentrations are higher in large than in small Dreissena (H. Morrison, personal communication). Waterfowl that feed on large mussels should experience greater exposure to contaminants. In this study, Greater Scaup consumed larger mussels and had higher contaminant concentrations than co-occurring Lesser Scaup and Bufflehead (Fig. 3; Table 1). Waterfowl exposure to organochlorine contaminants may, therefore, vary both as a function of the trophic level at which individuals feed, and by specialized (i.e., size-specific) feeding strategies employed by individual predators (Connolly and Pederson 1988, Koslowski et al. 1994). It is also possible that physiological differences among waterfowl species could account for some of the observed variation in contaminant concentrations. Observed differences were not related to sex or age of waterfowl studied (Table 1).

The relationship between contaminants and diet in scaup was site dependent, as mussel consumers from Fighting Island were more contaminated than individuals that ate macrophytes, but less contaminated than individuals from Lake Erie that consumed mussels (Table 1; Fig. 2). The latter pattern was surprising because Dreissena from Fighting Island were more contaminated than mussels from Lake Erie for a number of congeners (Table 1). This pattern may have resulted from subtle diet differences, as Lake Erie ducks consumed $>97 \%$ mussels, while those from Fighting Island also consumed macrophytes (15-24\%) (Fig. 2).

Differences in contaminant concentrations in conspecific plant and mussel consumers from Fighting Island were most pronounced for highly hydrophobic congeners (Table 1). Congeners such as PCBs 180, 194, and 206 were between 18 and 23 times higher in scaup that consumed Dreissena as a principal food than in those that ate mainly plants. Bufflehead that consumed mussels were also more contaminated with mid- and high- $K_{\text {ow }}$ congeners than those that ate mainly plants (Table 1). Bufflehead from Fighting Island had the highest total PCB concentration among waterfowl that consumed mainly macrophyte diets (Table 1). These individuals consumed $20 \%$ animal matter and had stable isotope values consistent with Dreissena diet (Table 1; Fig. 5). Highly hydrophobic compounds like PCBs 194 and 206 have very high- $K_{\text {ow }}$ values and correspondingly low elimination rate constants. These compounds are retained in biota to a higher degree than low- $K_{\text {ow }}$ congeners that are more easily excreted (Brieger and Hunter 1993, Morrison et al. 1995).

Herring Gulls nesting on Middle Sister Island (Lake Erie) have total PCB concentrations at least one order of magnitude higher than Lake Erie scaup from this study (G. Fox, personal communication). Greater and Lesser Scaup wet mass p,p'-DDE (dichlorodiphenyldichloroethene) levels are also at least two orders of magnitude lower than those reported for Double-crested Cormorant and Caspian Tern eggs from a variety of Great Lakes locations (Yamashita et al. 1993). These results are not surprising considering that fish-eating birds feed at a higher trophic level than waterfowl that consumed mussels in this study. 
Peterson and Fry (1987) reported that $\delta^{15} \mathrm{~N}$ ratios typically increase at least $3 \%$ with each increase in trophic level. Evidence from this study illustrates that trophic-level enrichment of $\delta^{15} \mathrm{~N}$ occurred in Lake Erie waterfowl relative to Dreissena prey, averaging $2.6 \%$ in Lesser Scaup and Bufflehead and 2.3\%o in Greater Scaup (Fig. 6). Lesser and Greater Scaup from Fighting Island that consumed mussels were enriched 2.3 and $1.3 \%$ relative to Dreissena, respectively. These ducks also were enriched by 2.5 and $1.4 \%$, respectively, relative to co-occurring conspecifics that consumed mainly macrophytes (Fig. 6). These examples of trophic enrichment of nitrogen isotopes in waterfowl complement contaminant data.

Stable isotope results for waterfowl that consumed macrophyte diets were less clear and, in some cases, in apparent contradiction to results for contaminants. For example, Redhead, Canvasback, and Bufflehead from Fighting Island had low contaminant concentrations and diets dominated $(\geq 88.6 \%)$ by macrophytes, yet each species exhibited $\delta^{15} \mathrm{~N}$ enrichment characteristic of Dreissena diet (Table 1; Fig. 5). Low contaminant concentrations in these ducks are consistent with recent consumption of macrophytes, while elevated $\delta^{15} \mathrm{~N}$ values may reflect recent (i.e., within the past month) utilization of animal prey. Consistent with this view, Custer and Custer (1996) determined that Dreissena comprised between 1.3 and $50.5 \%$ of diets of Redhead and Canvasback captured on Lakes Erie and St. Clair. Hobson and Clark (1992) reported a half-life for isotopes examined of $\sim 12.5 \mathrm{~d}$ for inactive ducks. Considering that all ducks surveyed here were active prior to being killed, and that active individuals have rapid turnover of proteins and of stable isotopes, $12.5 \mathrm{~d}$ should be treated as the maximum possible half-life (Hobson 1990; K. Hobson, personal communication). Therefore, diet and contaminant analyses indicate a vegetative diet for these waterfowl, although $\delta^{15} \mathrm{~N}$ values and literature reports suggest that these taxa may have consumed mussels in the recent past. Because diets of Canvasback and Redhead ducks are typically composed of vegetative matter (E. Mazak, personal observation), periodic opportunistic feeding on animals (e.g., Dreissena) could have a large but ephemeral impact on $\delta^{15} \mathrm{~N}$ values but not contaminant levels.

$\delta^{13} \mathrm{C}$ profiles of waterfowl that consumed Dreissena, as well as of those suspected of eating animal matter (Redhead, Canvasback, and Bufflehead), are consistent with a Dreissena dietary component (Fig. 5). However, $\delta^{13} \mathrm{C}$ profiles of Mallard and Greater and Lesser Scaup from Fighting Island that consumed mainly macrophytes were not consistent with those expected of animals with a macrophyte diet (Fig. 5). Rather, $\delta^{13} \mathrm{C}$ levels in these ducks were highly variable but most similar to those of epiphytic algae and intermediate to those of terrestrial plants $(-28 \%$ ) and macrophytes (approximately -10\%o) (Peterson and Fry 1987, Hamilton et al. 1992; R. Hesslein, unpublished data). Al- ternatively, $\delta^{13} \mathrm{C}$ signatures in these waterfowl may have been affected by earlier consumption of Dreissena prey.

\section{Reproductive impairment}

Reproductive problems associated with organochlorine contaminants have been reported for a number of waterbirds on the Great Lakes (see Fox 1993). Concern has centered on the possibility that waterfowl that consume contaminated Dreissena may experience reproductive impairment owing to accumulation of high contaminant burdens. Reproductive success in Tufted Ducks fed contaminated Dreissena was $60 \%$ lower than that of ducks fed less contaminated mussels (de Kock and Bowmer 1993). Lake Erie Greater Scaup, the most contaminated group of waterfowl in this study, had liver concentrations of PCBs 138, 153, and 180 that were between 17 and $54 \%$ of the levels found in the reproductively impaired Tufted Ducks. It is not clear whether any of the species of waterfowl included in this study have experienced contaminant-induced reproductive impairment. The number of Greater and Lesser scaup documented in all flyways of the United States and Canada during midwinter counts declined steadily between the late 1960s and the mid-1980s, though numbers appeared to increase along the Atlantic coast during the late 1980s (see Barclay and Zingo 1993). Recent surveys indicate that both Bufflehead and Common Goldeneye have declined in abundance in eastern North America (G. Fox, personal communication). Greater Scaup fly through, among other areas, the Lake Erie region during migrations to and from arctic breeding grounds. During 1993, Greater Scaup suffered an unusually high $(37.5 \%)$ rate of reproductive failure in Alaska (J. Barclay, personal communication). However, it has not been established whether these scaup had previously staged on Lake Erie nor whether their diet included Dreissena. Lesser Scaup chicks reared on a diet of Dreissena from Middle Sister Island had depressed vitamin A levels and a compromised immune system (C. Tessier, personal communication). These chicks accumulated a total PCB concentration of $1600 \mu \mathrm{g} / \mathrm{kg}$ lipid, whereas values in Lake Erie Greater Scaup, Lesser Scaup, and Bufflehead were 4464, 2734 , and $3722 \mu \mathrm{g} / \mathrm{kg}$ lipid, respectively. Even though waterfowl from Lake Erie that consumed Dreissena accumulated higher levels of PCBs than captive individuals that exhibited metabolic impairment, additional work is required to determine whether wild populations of waterfowl that frequent the Great Lakes are adversely affected by contaminated food.

In summary, three taxa of waterfowl in the lower Great Lakes that utilize Dreissena polymorpha as a primary food source exhibit elevated tissue concentrations for a broad suite of organochlorine congeners relative to individuals with macrophyte diet. Stable isotope analyses of conspecific groups of waterfowl with Dreissena and macrophyte diets revealed trophic en- 
richment in individuals with mussel diet. It is not yet clear whether any of the waterfowl taxa that exploited Dreissena experience adverse health effects in consequence.

Invasion of Lake Erie by zebra mussels has resulted in dramatic and rapid shifts in food web and contaminant dynamics (MacIsaac 1996). These changes parallel in strength, and may exceed in duration, responses by lakes subjected to intentional or unplanned biomanipulation of fishes (e.g., Vanni et al. 1990, Scheffer et al. 1993, Carpenter et al. 1996). Dispersal and establishment of Dreissena in lakes and rivers throughout eastern North America may portend significant changes in many invaded systems, and provide opportunities for ecologists to address questions relating to community assembly, food web interactions, and contaminant dynamics.

\section{ACKNOWLEDGMENTS}

We thank Dr. R. Alisauskas, T. Mayrand, B. Klingbyle, J. Bocchini, G. Penner, and R. Young for assistance in collecting waterfowl, and N. North for waterfowl identification. Dr. R. Lazar and B. Ross provided expert contaminant and stable isotope analyses, respectively. Discussions with M. Weis, R. Russell, D. Haffner, H. Morrison, S. Roe, R. Coulas, C. Tessier, J. Barclay, C. Custer, T. Custer, K. Hobson, and particularly G. Fox provided valuable insights. Comments by anonymous reviewers and $\mathrm{J}$. Wiens improved the manuscript. This study was supported by grants from the Canadian Wildlife Service (Wildlife Toxicology Fund), Ontario Ministry of Environment and Energy, and NSERC to H. J. MacIsaac.

\section{Literature Cited}

Barclay, J. S., and J. M. Zingo. 1993. Winter scaup populations in Connecticut coastal waters. Connecticut Warbler 13:136-150.

Brieger, G., and R. D. Hunter. 1993. Uptake and depuration of PCB 77, PCB 169, and hexachlorobenzene by zebra mussels (Dreissena polymorpha). Ecotoxicology and Environmental Safety 26:153-165.

Bruner, K. A., S. W. Fisher, and P. F. Landrum. 1994. The role of the zebra mussel Dreissena polymorpha, in contaminant cycling. 1. The effects of body size and lipid content on the bioconcentration of PCBs and PAHs. Journal of Great Lakes Research 20:725-734.

Cabana, G., and J. B. Rasmussen. 1994. Modelling food chain structure and contaminant bioaccumulation using stable nitrogen isotopes. Nature 372:255-257.

Carney, S. M. 1992. Species, age and sex identification of ducks using wing plumage. U.S. Fish and Wildlife Service, Washington, D.C., USA.

Carpenter, S. R., J. F. Kitchell, K. L. Cottingham, D. E. Schindler, D. L. Christensen, D. M. Post, and N. Voichick. 1996. Chlorophyll variability, nutrient input, and grazing: evidence from whole-lake experiments. Ecology 77:725-735.

Carter, D. S., and R. A. Hites. 1992. Fate and transport of Detroit River pollutants throughout Lake Erie. Environmental Science and Technology 26:1333-1341.

Cleven, E. J., and P. Frenzel. 1993. Population dynamics and production of Dreissena polymorpha (Pallas) in River Seerhein, the outlet of Lake Constance (Obersee). Archiv für Hydrobiologie 127:395-407.

Connolly, P., and C. J. Pederson. 1988. A thermodynamicbased evaluation of organic chemical accumulation in aquatic organisms. Environmental Science and Technology 22:99-103.

Custer, C. M., and T. W. Custer. 1996. Food habits of diving ducks in the Great Lakes after the zebra mussel invasion. Journal of Field Ornithology 67:86-99.

Dahl, J. A., D. M. Graham, R. Dermott, O. E. Johannsson, E. S. Millard, and D. D. Miles. 1995. Lake Erie 1993, western, west central and eastern basins: change in trophic status, and assessment of the abundance, biomass and production of the lower trophic levels. Canadian Technical Report of the Fisheries and Aquatic Sciences. Number 2070.

Davis, T. E., and R. M. Erwin. 1982. Potential effects of extended winter navigation upon migratory birds of the upper U.S. Great Lakes. FWS/OBS-82-151 and U.S. Army Corps of Engineers Technical Report.

de Kock, W. C., and C. T. Bowmer. 1993. Bioaccumulation, biological effects, and food chain transfer of contaminants in the zebra mussel (Dreissena polymorpha). Pages 503533 in T. F. Nalepa and D. W. Schloesser, editors. Zebra mussels: biology, impacts, and control. Lewis Publishers, Boca Raton, Florida, USA.

Duursma, E. K., J. Niewenhuize, and J. M. van Liere. 1984. Organochlorine contamination of the Dutch delta region as 'watched' by mussels. Water Science and Technology 16: 619-622.

Fry, B., and R. B. Quinones. 1994. Biomass spectra and stable isotope indicators of trophic level in zooplankton of the northwest Atlantic. Marine Ecology Progress Series 112:201-204.

Fox, G. A. 1993. What have biomarkers told us about the effects of contaminants on the health of fish-eating birds in the Great Lakes? The theory and a literature review. Journal of Great Lakes Research 19:722-736.

Gebauer, M. B., and D. V. Weseloh. 1993. Accumulation of organic contaminants in sentinel mallards utilizing confined disposal facilities at Hamilton Harbour, Lake Ontario, Canada. Archives of Environmental Contamination and Toxicology 25:234-243.

Hamilton, D. J. 1992. A method for reconstruction of zebra mussel (Dreissena polymorpha) length from shell fragments. Canadian Journal of Zoology 70:2486-2490.

Hamilton, D. J., D. Ankney, and R. C. Bailey. 1994. Predation of zebra mussels by diving ducks: an exclosure study. Ecology 75:521-531.

Hamilton, S. K., W. M. Lewis, Jr., and S. J. Sippel. 1992. Energy sources for aquatic animals in the Orinoco River floodplain: evidence from stable isotopes. Oecologia 89: 324-330.

Hesslein, R. H., D. E. Fox, and M. S. Capel. 1989. Sulfur, carbon, and nitrogen isotopic composition of fish from the Mackenzie River delta region and other Arctic drainages. Canadian Data Report of Fisheries and Aquatic Sciences 728.

Hobson, K. A. 1990. Stable isotope analysis of marbled murrelets: evidence for freshwater feeding and determination of trophic level. Condor 92:897-903.

Hobson, K. A. and R. G. Clark. 1992. Assessing avian diets using stable isotopes. 1. Turnover of ${ }^{13} \mathrm{C}$ in tissues. Condor 94:181-188.

Keough, J. R., M. E. Sierszen, and C. A. Hagley. 1996. Analysis of a Lake Superior coastal food web with stable isotope techniques. Limnology and Oceanography 41:136146.

Kidd, K. A., D. W. Schindler, R. H. Hesslein, and D. C. G. Muir. 1995. Correlation between stable nitrogen isotope ratios and concentrations of organochlorines in biota from a freshwater food web. Science of the Total Environment 160/161:381-390.

Kirilik, R. M., M. R. Servos, D. M. Whittle, G. Cabana, and J. B. Rasmussen. 1995. Using ratios of stable isotopes to characterize the biomagnification of DDE, Mirex and PCB 
in a Lake Ontario pelagic foodweb. Canadian Journal of Fisheries and Aquatic Sciences 52:2660-2674.

Koslowski, S. E., C. D. Metcalfe, R. Lazar, and G. D. Haffner. 1994. The distribution of 42 PCBs, including three coplanar congeners, in the food web of the western basin of Lake Erie. Journal of Great Lakes Research 20:260-270.

Lazar, R., R. C. Edwards, C. D. Metcalfe, F. A. P. C. Gobas, and G. D. Haffner. 1992. A simple, novel method for the quantitative analysis of coplanar polychlorinated biphenyls in the environment. Chemosphere 25:493-504.

MacIsaac, H. J. 1996. Potential abiotic and biotic effects of zebra mussels on the inland waterways of North America. American Zoologist 36:287-299.

Mazak, E. J. 1995. Organic contaminants in lower Great Lakes' waterfowl in relation to diet, with particular reference to Dreissena polymorpha. Master's thesis. University of Windsor, Windsor, Ontario, Canada.

Mills, E. L., J. H. Leach, J. T. Carlton, and C. L. Secor. 1993. Exotic species in the Great Lakes: a history of biotic crises and anthropogenic introductions. Journal of Great Lakes Research 19:1-54.

Mitchell, C. A., and J. Carlson. 1993. Lesser scaup forage on zebra mussels at Cook Nuclear Plant, Michigan. Journal of Field Ornithology 64:219-222.

Morrison, H., T. Yankovich, R. Lazar, and G. D. Haffner 1995. Elimination rate constants for 36 PCBs in zebra mussels (Dreissena polymorpha) and exposure dynamics in the Lake St. Clair-Lake Erie corridor. Canadian Journal of Fisheries and Aquatic Sciences 52:2574-2582.

Nalepa, T. F., and D. W. Schloesser. 1993. Zebra mussels biology, impacts, and control. Lewis Publishers, Boca Raton, Florida, USA.

Nebeker A. V., K. D. Dunn, W. L. Griffis, and G. S. Schuytema. 1994. Effects of dieldrin in food on growth and bioaccumulation in mallard ducklings. Archives of Environmental Contamination and Toxicology 26:29-32.

Peterson, B. J. and B. Fry. 1987. Stable isotopes in ecosystem studies. Annual Review of Ecology and Systematics 18 293-320.

Prince, H. H., P. I. Padding, and R. W. Knapton. 1992. Waterfowl use of the Laurentian Great Lakes. Journal of Great Lakes Research 18:673-699.
Riera, P., and P. Richard. 1996. Isotopic determination of food sources of Cassostrea gigas along a trophic gradient in the Estuarine Bay of Marennes-Oléron. Estuarine, Coastal and Shelf Science 42:347-360.

Robertson, A., G. G. Lauenstein, and S. Dolvin. 1993. Great Lakes mussel watch: organic contaminant levels from Saginaw Bay to western Lake Erie. Thirty-sixth Conference of the International Association for Great Lakes Research, DePere, Wisconsin (Abstract).

Roe, S., and H. J. MacIsaac. 1997. Temporal variation of organochlorine contaminants in the zebra mussel Dreissena polymorpha. Aquatic Toxicology, in press.

Scheffer, M., S. H. Hosper, M-L. Meijer, B. Moss, and E. Jeppesen. 1993. Alternative equilibria in shallow lakes. Trends in Ecology and Evolution 8:275-279.

Shui, W. Y., and D. Mackay. 1986. A critical review of aqueous solubilities, vapor pressures, Henry's Law constants, and octanol-water partition coefficients of the polychlorinated biphenyls. Journal of Physical Chemistry Reference Data 15:911-929.

Stańczykowska, A., P. Zyska, A. Dombrowski, H. Kot, and E. Zyska. 1990. The distribution of waterfowl in relation to mollusc populations in the man-made Lake Zegrezynskie. Hydrobiologia 191:233-240.

SYSTAT. 1992. Version 5.01. SYSTAT Inc., Evanston, I1linois, USA.

Tabachnick, B. G., and L. S. Fidell. 1996. Using multivariate statistics. Third edition. Harper Collins, New York, New York, USA.

Vanni, M. J., C. Luecke, J. F. Kitchell, Y. Allen, J. Temte, and J. J. Magnuson. 1990. Effects on lower trophic levels of massive fish mortality. Nature 344:333-335.

Wormington, A., and J. H. Leach. 1992. Concentrations of migrant ducks at Point Pelee National Park, Ontario, in response to invasion of zebra mussels, Dreissena polymorpha. Canadian Field Naturalist 106:376-380.

Yamashita, N., S. Tanabe, J. P. Ludwig, H. Kurita, M. E. Ludwig, and R. Tatsukawa. 1993. Embryonic abnormalities and organochlorine contamination in double-crested cormorants (Phalacrocorax auritus) and Caspian terns (Hydroprogne caspia) from the upper Great Lakes in 1988. Environmental Pollution 79:163-173. 